\title{
Airboat Use and Disturbance of Floating Mat Fen Wetlands in Interior Alaska, U.S.A.
}

\author{
CHARLES H. RACINE, ${ }^{1}$ JAMES C. WALTERS ${ }^{2}$ and M. TORRE JORGENSON ${ }^{3}$
}

(Received 27 October 1997; accepted in revised form 7 May 1998)

\begin{abstract}
The use of airboats is expanding in Alaska, particularly in the interior. This study describes the nature, magnitude, and distribution of disturbances caused by airboat trails over floating mat fen wetlands in the Tanana Flats near Fairbanks, Alaska. Airphoto interpretation showed over $300 \mathrm{~km}$ of airboat trails by 1995, with a 15\% expansion of the trail system since 1989 . Field sampling was done at 30 trail and adjacent control sites along this trail system to assess changes in hydrology, soils, and vegetation. Water velocities in the trails at two-thirds of the sites were at least an order of magnitude greater than velocities of less than $1.5 \mathrm{~cm} \mathrm{sec}^{-1}$ in the control areas. On average, $30 \mathrm{~cm}$ of the $0.5-0.75 \mathrm{~m}$ thick floating mat has been removed or eroded by airboat traffic at the sampling locations. Nearly all emergent floating mat vegetation has been destroyed (5\% cover remaining on average) so that the trails resemble a highly visible open water stream channel 2-3 m wide through the floating mats. Although the recovery and regrowth potential of floating mats in trails is high, recovery is unlikely in trails with continuing use.
\end{abstract}

Key words: airboat, floating mat, Alaska, peatland, fen, wetland, disturbance

RÉSUMÉ. En Alaska, l'utilisation des hydroglisseurs est à la hausse, surtout à l'intérieur des terres. Cette étude décrit la nature, l'amplitude et la distribution des perturbations causées par le sillage des hydroglisseurs sur les zones humides de vasières à mattes flottantes situées dans les plaines marécageuses de Tanana près de Fairbanks (en Alaska). L’interprétation de photos a montré que, en 1995, les sillages d'hydroglisseurs s'étendaient sur plus de $300 \mathrm{~km}$, ce qui correspond à une augmentation de 15 p. cent du réseau depuis 1989. On a procédé à un échantillonnage sur le terrain à 30 emplacements de sillages et aires témoins adjacentes le long du réseau en vue d'évaluer les changements dans l'hydrologie, les sols et la végétation. Dans deux tiers des emplacements, la vitesse de l'eau dans les sillages était d'au moins un ordre de grandeur supérieure aux vitesses de moins de $1,5 \mathrm{~cm} \mathrm{sec}^{-1} \mathrm{dans}$ les zones témoins. Aux endroits d'échantillonnage, $30 \mathrm{~cm}$ en moyenne de la matte flottante épaisse de 0,5 à $0,75 \mathrm{~m}$ a été enlevée ou érodée par la circulation de l'hydroglisseur. Presque toute la végétation de la matte flottante émergée a été détruite (il reste en moyenne 5 p. cent du couvert) de sorte que les sillages sont très visibles et forment un chenal d'eau ouverte de 2 à $3 \mathrm{~m}$ de large à travers les mattes flottantes. Bien que le potentiel de recouvrement et de repousse des mattes flottantes dans les sillages soit élevé, il est peu probable que ce recouvrement ait lieu dans les sillages qui sont utilisés de façon continue.

Mots clés: hydroglisseur, matte flottante, Alaska, tourbière, vasière, terre humide, perturbation

Traduit pour la revue Arctic par Nésida Loyer.

\section{INTRODUCTION}

Airboats, which are well known in southern swamps and marshes of the United States, have become increasingly common in Alaska because they can traverse remote wetland areas not accessible on foot or by conventional boat. The airboat is a smooth, flat-bottomed boat $(2 \mathrm{~m}$ wide, $3-5 \mathrm{~m}$ long, and weighing 360 to $900 \mathrm{~kg}$ ), designed to operate in extremely shallow water and capable of crossing short stretches of gravel bars, mud banks, and scrub. An automotive or aircraft engine that turns one or two propellers is mounted on the stern to move these boats at speeds up to $80 \mathrm{~km} / \mathrm{hr}$. They are noted particularly for being extremely noisy and creating strong winds behind the boat.
One area where airboat use has increased and generated recent controversy is interior Alaska, particularly in the vicinity of Fairbanks, which is located at the confluence of the shallow Chena and Tanana Rivers. Airboats are well suited for use on these rivers, as well as on a unique nearby system of floating mat fens, which covers $100 \mathrm{~km}^{2}$ in the northwestern corner of the Tanana Flats (Racine and Walters, 1994; Jorgenson et al., 1996) (Figs. 1 and 2). Here, airboats are used between May and October for hunting, recreational travel, cabin access, and even commercial sightseeing tours. In the summer, airboats are the only means of access into this area, other than by helicopter or on foot. Airboats have been operated here for at least two decades, but in the past few years the number of users has increased dramatically.

\footnotetext{
${ }^{1}$ U.S. Army Cold Regions Research and Engineering Laboratory, Hanover, New Hampshire 03755 U.S.A.; cracine@ usace.army.mil

${ }^{2}$ Department of Earth Science, University of Northern Iowa, Cedar Falls, Iowa 50614, U.S.A.

3 Alaska Biological Research Inc., P.O. Box 80410, Fairbanks, Alaska 99708, U.S.A.

(C) The Arctic Institute of North America
} 

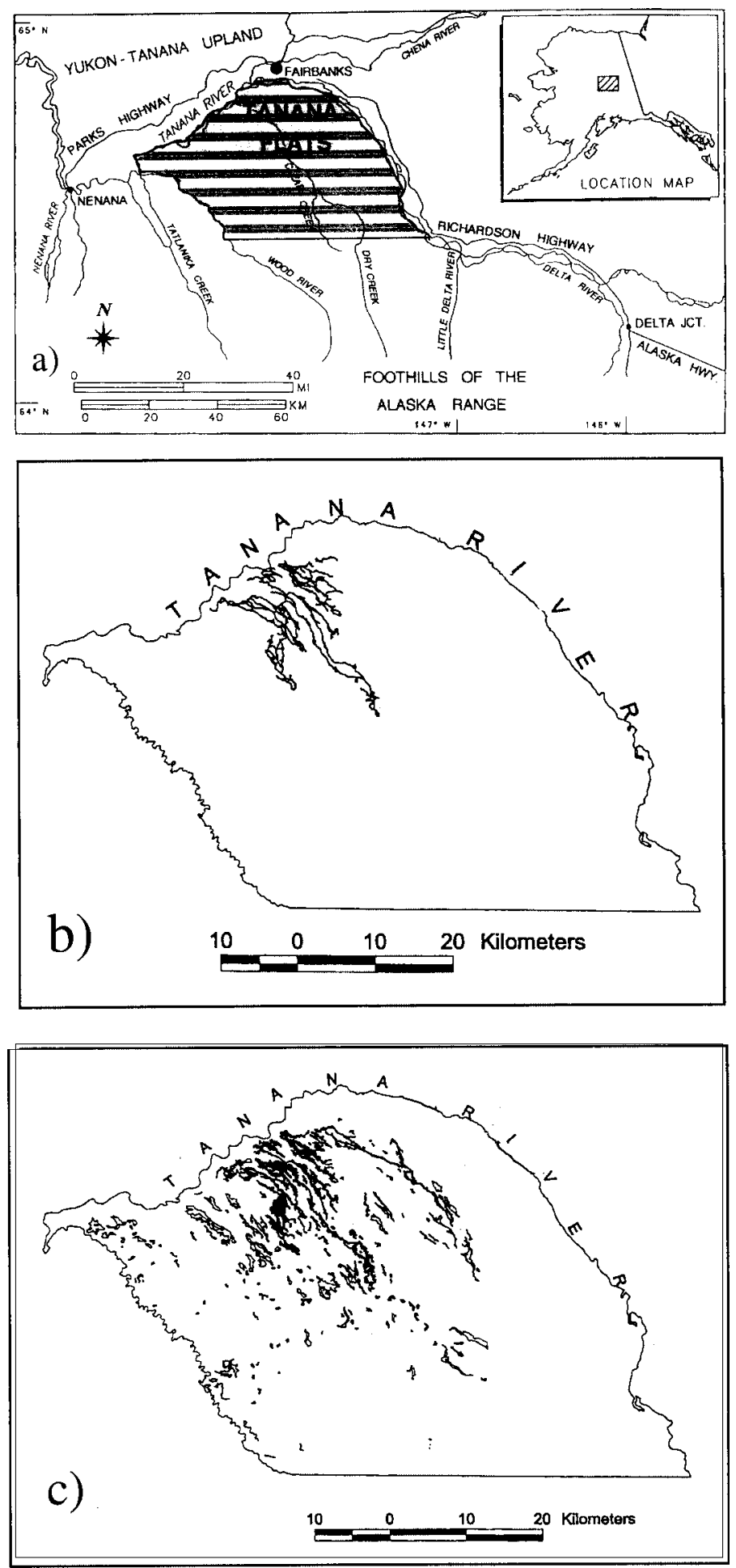

FIG. 1. Maps showing: a) the Tanana Flats and their location in Alaska (inset) (shaded area is on Ft. Wainwright) b) outline of shaded area in a), showing the distribution of airboat trails on the Tanana Flats in September 1995. c) same outline of shaded area in a), showing the distribution of floating mat fens as mapped by Jorgenson et al. (1996).

Concerns over potential impacts on wetland ecosystems have been increasing because of the increasing use of the airboats. Possible negative environmental effects include disturbance to waterfowl (Mabie et al., 1989) and other wildlife and damage to stream banks, vegetation, and

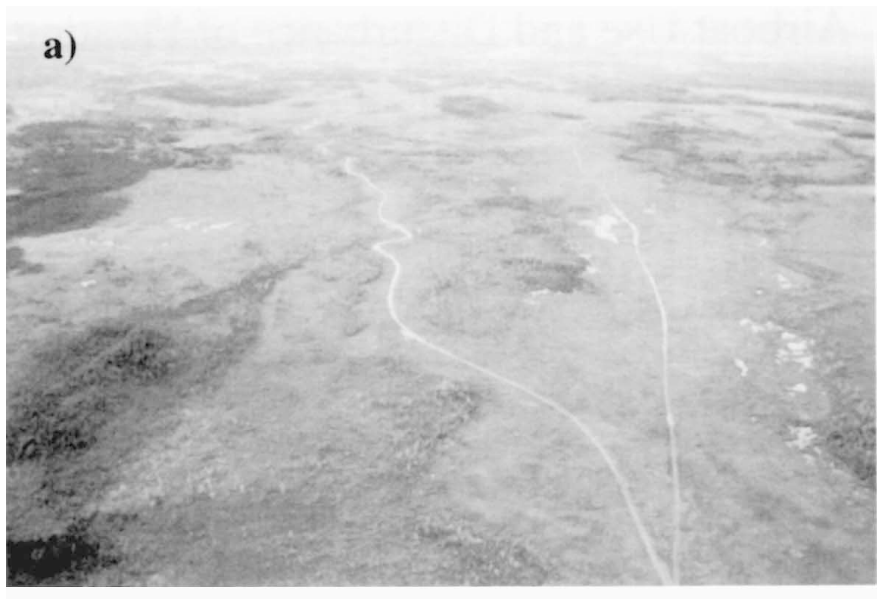

b)

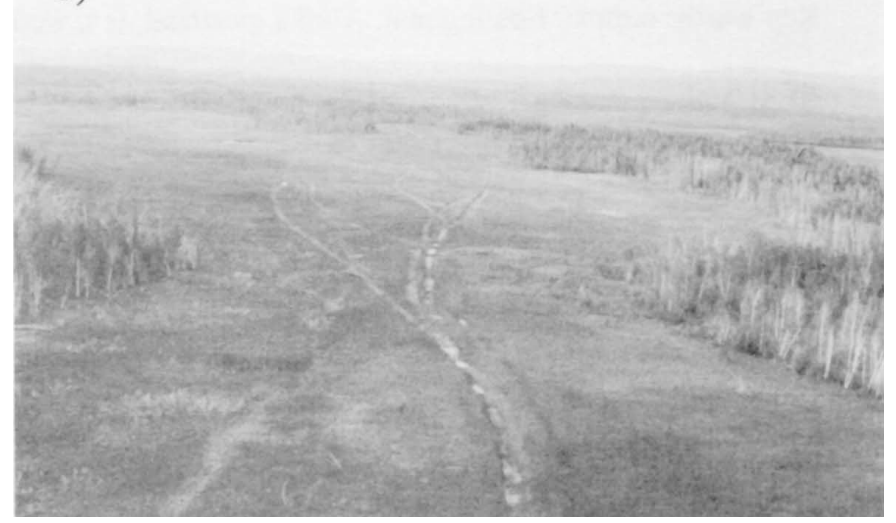

FIG. 2. Aerial oblique photos of floating mat fens showing: a) highly visible open-water channels of airboat trails in floating mat fens and b) main trails and branching secondary trails over a drier section of floating mat fen. Note small pools of water in trail and exposed organic soils as well as "drowning" birch forests along the fen edge.

underlying soils, with the associated loss of habitat and changes in the water flow regime. In addition, there have been major conflicts among area residents, recreationists, and subsistence hunters over noise levels and perceptions of unfair hunting practices. In 1996, hunting regulations issued by the Alaska Department of Fish and Game banned the use of airboats for moose hunting in both the Nenana Controlled Use Area and the Minto Flats, areas in the Tanana Lowland just west of our study area. Although airboats are too expensive for most subsistence users in rural Alaska, airboat owners from Fairbanks and Anchorage can transport their vehicles to some of these more remote areas.

Because part of the area used by airboats is within the $3700 \mathrm{~km}^{2}$ military reservation managed by the U.S. Army at Ft. Wainwright (Fig. 1a), the Army initiated a study to determine use and impacts of airboats in this area in 1989. Of major concern are the effects of airboat travel on vegetation, soils, and water flow of the wetlands and the impact of noise and wind blast on wildlife. The purpose of this study was to evaluate the extent of airboat use and to characterize the nature of disturbance to floating mats and water flow on the Tanana Flats. 


\section{STUDY AREA}

The Tanana Flats make up the east-central portion of the middle Tanana Lowland, a broad depression between the Alaska Range to the south and the Yukon-Tanana Upland to the north (Péwé, 1975; Fig. 1a). The climate here is continental and subarctic, with a mean annual temperature in Fairbanks of $-3.3^{\circ} \mathrm{C}$, and it is subarid, with little or no water surplus. Yearly precipitation averages $28.4 \mathrm{~cm}$, with a minimum in late winter and a maximum in late summer (Viereck et al., 1993).

Both surface and subsurface water move slowly across the Tanana Flats from southeast to northwest, from the Alaska Range to the Tanana River. The subsurface groundwater appears to discharge to the surface as springs toward the northwest corner of the Tanana Flats. As a result, an area of highly productive minerotrophic fens has developed, which contain this groundwater and support an almost continuous floating vegetation mat and rich fen (Racine and Walters, 1994) (Figs. 1b and 2). These fens show no surface patterns, and there are very few openwater ponds, pools, or streams. Water moves slowly through the floating mat fens on a gradient of less than 0.1 to $0.2 \%$, finally reaching the Tanana River through at least three outlet channels. In this area, these floating mat fens, which cover about $100 \mathrm{~km}^{2}$, include at least three large groups of hydrologically connected fens and some smaller, isolated outliers (Fig. 1b). The fens contain no permafrost but are bordered by low scrub and forests of black spruce and paper birch with permafrost. Rapid permafrost degradation is occurring where the birch forests border the fens (Racine et al., in press).

\section{METHODS}

\section{Mapping and Spatial Analysis}

Airboat trails were interpreted and mapped onto mylar sheets overlaid on composites of 1:24 000-scale true-color aerial photos obtained in mid-September of both 1989 and 1995. An attempt was made to distinguish between highly visible, darker "main" airboat trails (with exposed water or organic soil) and lighter-toned "secondary" trails, where the vegetation had been depressed (Fig. 2b). These photointerpreted trails were then digitized from the mylar into the Arc/Info Geographic Information System to calculate total lengths and to analyze their spatial pattern in relation to wetlands, as mapped by Jorgenson et al. (1996) using these same photos.

\section{Field Measurements}

To evaluate airboat disturbances to floating mat fens, we compared conditions in the undisturbed floating mat with disturbed conditions in the airboat trails. A total of 40 sites (30 paired and 10 unpaired sites) were visited by airboat or helicopter, chosen at random along most of the major airboat trail systems. At the paired sites, measurements were made in the trail and in an undisturbed control area 5 to $10 \mathrm{~m}$ away from the trail.

Stratigraphy of the undisturbed floating mat was accomplished by coring with a $10 \mathrm{~cm}$ diameter PVC tube fitted with a serrated edge for cutting through roots and rhizomes. The cores were cut in half lengthwise and the basic stratigraphy described. Some cores were returned to the laboratory for determinations of bulk density, composition, and percentage of organic matter (Boelter, 1969). Where the corer did not reach the underlying mineral substrate, the depth to silt was determined by probing with a $2 \mathrm{~m}$ long metal rod. At some sites, we also measured the relative buoyancy and degree of consolidation of the mat by stepping onto the mat with our weight $(75 \mathrm{~kg}$ ) on one leg and measuring how far the mat was depressed.

Water depth in relation to the floating mat surface was measured at several points off to the side of the trail, in an undisturbed area, and in the trail (to the identified material at the bottom of the trail). The hole made by the corer was used to determine the depth to the water table where the water table was below the surface of the floating mat. Water velocities were measured with a Marsh-McBirney Model 2000 electromagnetic flowmeter (which can detect flows as low as $1.5 \mathrm{~cm} / \mathrm{sec}$ ) at several points in the center of the trail at a depth of $10 \mathrm{~cm}$, in the control area above, and in the undisturbed mat. Water temperature and chemistry ( $\mathrm{pH}$ and conductivity) measurements were made in the trail and control areas at a depth of $10 \mathrm{~cm}$ with a YSI Model 2500 water quality meter.

Other site measurements include: 1) trail width and orientation; 2) emergent vegetation cover, estimated by species in the trail and in the control area; and 3) peat exposure above the water surface in or along the edge of the trail, rated as $0=$ none, $1=$ slight, $2=$ moderate, or $3=$ high. Also noted was the presence or absence of suspended organic particulates moving in the water in the trail.

The field measurement data were analyzed by calculating descriptive statistics. Paired or unpaired t-tests were used where appropriate to detect significant differences in measured field parameters between the trail and control areas.

\section{RESULTS}

\section{Trail Distribution}

In 1989, the total length of photo-interpreted trails was $263 \mathrm{~km}$, of which $37 \%(99 \mathrm{~km})$ were heavily used main trails, 54\% (143 km) were less-used secondary trails, and $8 \%(22 \mathrm{~km})$ were trails on existing streams (Table 1). By 1995 , the total length of airboat trails had increased by $15 \%$, to $303 \mathrm{~km}$. During this period, trails were extended toward the southeast into the Tanana Flats, from $17 \mathrm{~km}$ from the Tanana River access points in 1989 to $26 \mathrm{~km}$ by 
TABLE 1. Total lengths of airboat trails mapped from September aerial photos taken in 1989 and 1995.

\begin{tabular}{lrc}
\hline \hline Trail Type & 1989 airphoto & 1995 airphoto \\
\hline Main trails & $99 \mathrm{~km}$ & $107 \mathrm{~km}$ \\
Secondary trails & $143 \mathrm{~km}$ & $172 \mathrm{~km}$ \\
Stream trails & $22 \mathrm{~km}$ & $24 \mathrm{~km}$ \\
Total & $264 \mathrm{~km}$ & $303 \mathrm{~km}$ \\
\hline \hline
\end{tabular}

1995 (Fig. 1b). Many of the secondary trails are represented by side-trail loops or parallel trails off the main trails in the larger fens, where airboats make exploratory trips. In the narrow fens to the southeast, there is usually only a single airboat trail.

All of the mapped airboat trails are located in the "fen meadow" unit mapped by Jorgenson et al. (1996) on the Tanana Flats portion of Ft. Wainwright (Fig. 1c). These include 217 fen meadow patches covering a total of $104 \mathrm{~km}^{2}$. Airboat trails pass through about 100 of these fen meadow patches, which collectively cover $50 \mathrm{~km}^{2}$, or onehalf of the area represented by these fens.

\section{Undisturbed Conditions}

The floating mat, which varied in thickness from 50 to $75 \mathrm{~cm}$, consisted of a dense, fibric matrix of small live rootlets $(<1.0 \mathrm{~mm}$ diameter $)$ and occasional rhizomes $(0.5$ to $1.0 \mathrm{~cm}$ diameter) with embedded small $(0.1-0.5 \mathrm{~mm})$ black unrecognizable organic particulates or peat (Fig. 3). The black particulates, which comprised about $40 \%$ of the mat by dry weight, probably represent the partially decomposed leaf and stem litter deposited annually by the highly productive mats. The specific gravity of the upper mat (at a depth of 10 to $20 \mathrm{~cm}$ ) is $0.12-0.18 \mathrm{~g} \mathrm{~cm}^{-3}$ on a dry weight basis and 0.80 to $0.95 \mathrm{~g} \mathrm{~cm}^{-3}$ on a wet weight basis. The mineral content of the floating mat increased with depth from less than $10 \%$ in the upper $30 \mathrm{~cm}$ of the mat to about $25 \%$ in the lower half of the mat. Below the mat there was often a clear water zone or lens above a $10-20 \mathrm{~cm}$ thick layer of sapric peat and silt over the gleyed silt $C$ horizon (Fig. 3). In fewer instances this peat layer was absent, and the mat rested directly on the alluvial silt. The average depth from the mat surface to the top of the silt layer was $120 \mathrm{~cm}$.

The water table at sample sites varied from $20 \mathrm{~cm}$ above the surface of the mat to $10 \mathrm{~cm}$ below the mat surface, with an average of $+8 \mathrm{~cm}$ (Fig. 3). Differences in the water table level were also noted in relation to season and rainfall. Sites with the highest water table were depressed the most $(30-50 \mathrm{~cm})$ when we stood on them on one leg, while sites with a lower water table were depressed only $5-15 \mathrm{~cm}$. The $\mathrm{pH}$ of the surface water averaged 6.7 or circumneutral, and conductivity averaged $350 \mu \mathrm{s} \mathrm{cm}^{-1}$. Water temperatures in mid-August averaged $16^{\circ} \mathrm{C}$.

The species composition of the undisturbed floating mats included the following, in order of importance: buckbean (Menyanthes trifoliata), horsetail (Equisetum fluviatile), sedges (Carex aquatilis, C. lasiocarpa), marsh

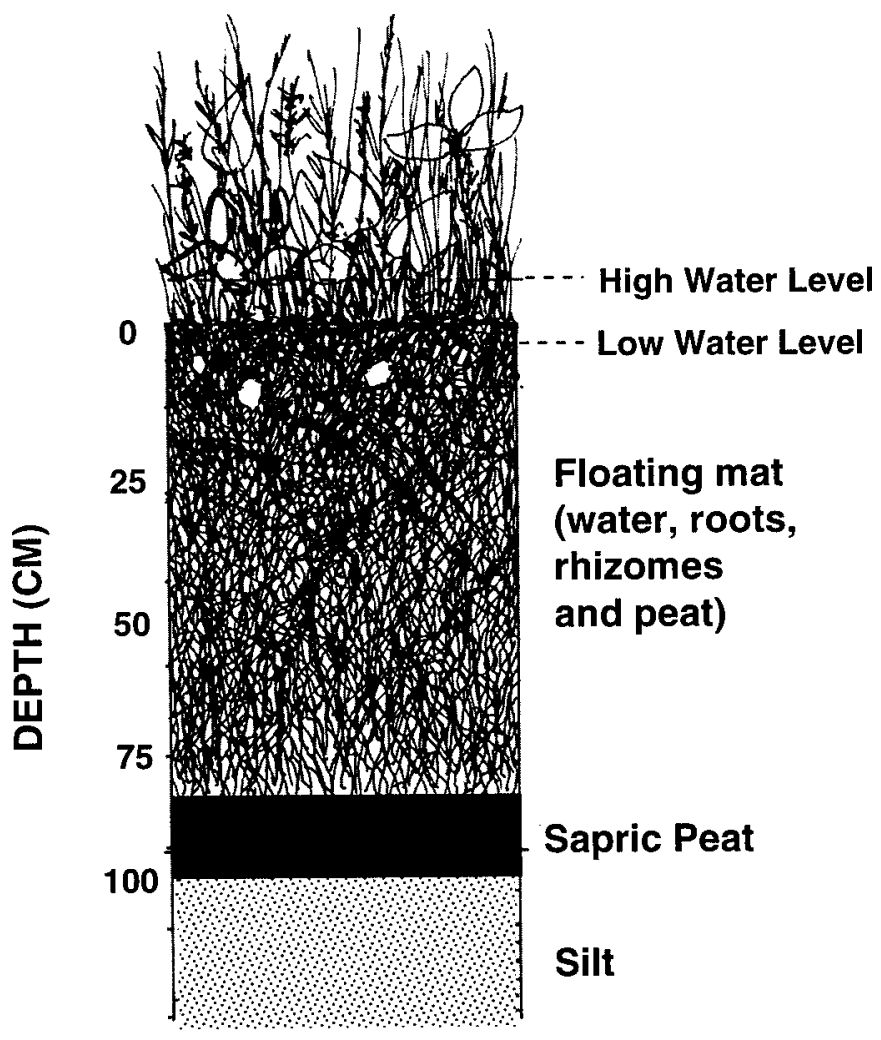

FIG. 3. Generalized floating mat and peat stratigraphy based on soil pits and cores obtained in control areas along airboat trails on the Tanana Flats.

five-fingers (Potentilla palustris), water-hemlock (Cicuta virosa), cattail (Typha latifolia), and occasional shrubs, such as willow (Salix candida), alder (Alnus tenuifolia), and sweet gale (Myrica gale). Moss cover was usually absent, although Calliergon sp. and Cinclidium sp. were occasionally present. At the 30 sample sites, buckbean was dominant at 16 sites, horsetail at 6 sites, sedges at 5, marsh five-fingers at 2 sites, and willow at 1 site. The emergent herbaceous overstory at most sites was 0.5 to $1.0 \mathrm{~m}$ tall, and clipped standing crop biomass approached $10000 \mathrm{~g} \mathrm{~m}^{-2}$.

\section{Airboat Trail Conditions}

Trail width at the 40 sites averaged $2.4 \mathrm{~m}$, and trails were most often oriented in the same direction as regional water flow, from SE to NW (Table 2, Fig. 1c). Water depths in the main trails averaged $33 \mathrm{~cm}$, whereas depths in the undisturbed floating mat averaged $8 \mathrm{~cm}$ (Table 2). The difference between water depths in the center of the trail and to the side over the undisturbed mat at each of the 30 sites averaged $25 \mathrm{~cm}$. A paired t-test showed a significant difference in water depth between the trails and the control areas $(\mathrm{t}=8.6 ; \mathrm{df}=29 ; p<.05)$. At all trail sites sampled, at least some of the floating mat remained on the bottom of the trail. Therefore, the silt bottom of the fens, at depths of 1-2 m (Fig. 3), was not exposed at any sampled trail site.

Water velocities in main trails were greater than the detection limit of $1.5 \mathrm{~cm} / \mathrm{sec}$ at 20 of the 30 main trail sites 
sampled (Table 2). Water flow could not be detected $(<1.5 \mathrm{~cm} / \mathrm{sec})$ at any of the remaining 10 main trails or at the 30 control sites off to the side of the main trails. Velocities in the 20 main trail sites where flow was detected averaged $12 \mathrm{~cm} \mathrm{sec}^{-1}$ (Table 2). On some trails with moving water, beavers have attempted to build small dams across the trail.

Displaced organic mat was visible above the water surface in or along the sides of the main trail at only 5 of the 30 sites sampled. Two situations where organic mat debris was exposed included: 1) material splashed and deposited along the sides of the trail, particularly on curves; and 2) exposed torn and damaged organic mat, where the water table is at or below the surface of the floating mat along the entire trail (Figs. $2 b$ and 3 ). In most trails with exposed organics, there was little or no detectable water flow, and the water table was below the surface of the mat.

Vegetation cover on the main trails averaged 5\%, whereas total live cover in the controls averaged $95 \%$. Buckbean leaves most often accounted for the small amount of live vegetation in main trails, and cover was generally higher in early summer before airboat traffic. It is difficult to estimate vegetation cover on secondary trails because much of the vegetation is flattened.

Water quality differed little between trails and undisturbed control areas. At 7 of the 30 sites, water temperatures in the main trails were very slightly higher than in the control areas in August. However, surface water conductivity and $\mathrm{pH}$ were not different between the trails and control areas. Suspension and movement of organic particulate material were also observed in the water at all main trail sites after airboat passage.

\section{DISCUSSION AND CONCLUSIONS}

Although much attention has been given to the impacts of several types of off-road vehicles (ORVs) in northern ecosystems (Rickard and Brown, 1974; Slaughter et al., 1990; Racine and Ahlstrand, 1991; Forbes, 1992; Emers et al., 1995), no attention has been given to airboats. In Alaska, areas inaccessible to conventional boats and ORVs include shallow rivers and streams, some wetlands near coastal areas, and several large Alaskan lowland basins, such as the Kuskokwim River-Nixon Flats area, the Yukon Flats, the Selawik Lowlands, and the Innoko Basin. In the Tanana Lowlands, airboats are being used in the floating mat fen area described here and on wetland-lake complexes in Minto Flats. About one-half of the $100 \mathrm{~km}^{2}$ of fens in the Tanana Flats have been traversed by airboats. There is thus potential for future expansion and penetration of airboat trails into other fens on the Tanana Flats, although access into some of these untracked areas may be difficult or impossible.

Preliminary evidence suggested that the floating mats described here should be fairly resistant to airboat damage:
TABLE 2. Descriptive statistics for airboat trail and control conditions measured at sample sites in floating mat fens on the Tanana Flats, Ft. Wainwright, Alaska.

\begin{tabular}{|c|c|c|c|c|}
\hline Trail and/or Control Character & Range & Mean & $\mathrm{SD}( \pm)$ & $\mathrm{N}$ \\
\hline Width (m) & $2-6$ & 2.4 & .9 & 30 \\
\hline Orientation (degrees) & $270-355$ & 313 & 29 & 20 \\
\hline \multicolumn{5}{|l|}{ Water depth $(\mathrm{cm})$} \\
\hline Control (over mat surface) & $0-20$ & 8 & 5 & 22 \\
\hline Main trail (water depth) & $5-60$ & 33 & 17 & 30 \\
\hline \multicolumn{5}{|l|}{ Water velocity $\left(\mathrm{cm} \mathrm{sec}^{-1}\right)$} \\
\hline Control $\left(\right.$ all $\left.<1.5 \mathrm{~cm} \mathrm{sec}^{-1}\right)$ & $<1.5$ & $<1.5$ & - & 30 \\
\hline Main trails with no detectable flow & $<1.5$ & $<1.5$ & - & 10 \\
\hline Main trails with detectable flow & $2-33$ & 12 & 8 & 20 \\
\hline \multicolumn{5}{|l|}{ Surface water temperature $\left({ }^{\circ} \mathrm{C}\right)$} \\
\hline Control & $11-16$ & 15.9 & 2.0 & 7 \\
\hline Trail & $12-17$ & 16.5 & 2.6 & 13 \\
\hline \multicolumn{5}{|l|}{ Water electrical conductivity $\left(\mu \mathrm{s} \mathrm{cm}^{-1}\right)$} \\
\hline Control & $100-400$ & 350 & 75 & 25 \\
\hline Trail & $110-400$ & 460 & 100 & 13 \\
\hline \multicolumn{5}{|l|}{ Water $\mathrm{pH}$} \\
\hline Control & $6.1-6.9$ & 6.5 & 0.5 & 10 \\
\hline Trail & $6.0-6.9$ & 6.7 & 0.3 & 13 \\
\hline \multicolumn{5}{|l|}{ Vegetation cover $(\%)$} \\
\hline Control & $80-100$ & 95 & 10 & 30 \\
\hline Trail & $0-20$ & 5 & 1 & 30 \\
\hline
\end{tabular}

1) a layer of water over the surface of most floating mats and depression of the mat with airboat passage should provide a water surface on which the airboat rides without direct contact with the mat; 2) a preliminary airboat test in which 50 straight-line passes of an airboat left the mat intact (but removed the emergent leaves and stems, Fig. 4); 3 ) analysis of the mat material revealed a strong, thick, and dense living root and rhizome mat; 4) studies by Krusi and Wein (1988) showed that floating Typha mats are resistant to both burning and drainage. Despite this evidence, the vegetation and soils of floating mat fens in the Tanana Flats have been severely damaged along main airboat trails: there are over $100 \mathrm{~km}$ of trails with open-water, stream-like channels on which all of the emergent vegetation and about $50 \%$ of the underlying mat have been destroyed.

Figure 5 shows how a channel in the floating mat could develop with repeated traffic over several years. Traffic over an undisturbed section of floating mat fen initially removes and depresses the emergent leaves and stems (Fig. 5a). Since this traffic begins in early summer and continues into the late fall, there is little chance for recovery, and the loss of photosynthetic tissue eventually results in the reduced growth and death of the large mass of underlying roots and rhizomes. Once a slight surface depression forms, the flow velocity of water increases from very low flows $(<1.5 \mathrm{~cm} / \mathrm{sec})$ to flows sufficient to remove loosened peat and dead root and rhizome components by erosion (Fig. 5b), leading to the deepening of the channel (Fig. 5c). Virtually all trails are oriented parallel to the direction of regional water movement, which contributes to the increased flow.

The amount of channelization of stream flow through the fens and the potential indirect effects of the 


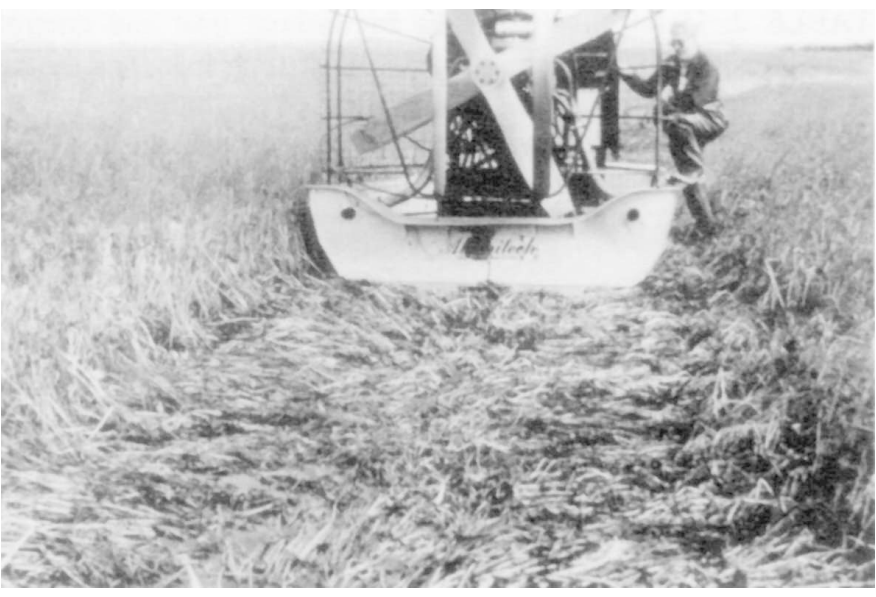

FIG. 4. Airboat and test lane used to conduct a preliminary evaluation of surface disturbance by an airboat driven back and forth 50 times over this test lane. The subsurface floating mat remained intact, although most of the emergent vegetation was removed or flattened beneath the water.

channelization on the hydrology and ecology of the fens are unknown, but are of concern. Groundwater flow through the fens is essential to the high productivity of these ecosystems, and alteration of the hydrologic regime by channelization could potentially reduce water levels and nutrient input. We speculate that the effect of channelization is negligible to minor, but we have not adequately evaluated this effect.

The floating mats of the type that are physically damaged by airboats in the Tanana Flats are often considered as an early stage in peatland succession (Kratz and DeWitt, 1986). They play an important role in regulating the hydrology, nutrient availability, thermal conditions, water tables, and succession in such wetlands (Hogg and Wein, 1988). In addition, the floating mat fens of the Tanana Flats appear to be extremely productive ecosystems, provide habitat for a variety of wildlife including moose, and intercept, regulate, and transform minerotrophic groundwater that might otherwise be lost more rapidly from this wetland ecosystem. It appears that the destruction of these floating mats by expanding airboat use can alter water flow patterns and rates, with associated increases in mineral and organic carbon export. In the Tanana Flats, there is good evidence from aerial photos that if airboat trails are not used for a period of a few years, the mat will regrow. The high productivity and minerotrophic nature of the Tanana Flats fens also suggest that damaged floating mats have a high potential for regrowth and recovery in the absence of continued traffic. Sjors (1988) found that live roots and rhizomes of buckbean may extend to $93 \mathrm{~cm}$, so that the potential for regrowth is high even where much of the floating mat has been destroyed along airboat trails described here.

On the basis of a total main trail length of $100 \mathrm{~km}$ and average trail width of $2.4 \mathrm{~m}$, we estimate that a total of 24 ha of fens have been damaged by airboat activity within the study area. In addition, there are several other areas where airboat use is prevalent, so overall direct impacts in
AIRBOAT TRAIL

a)

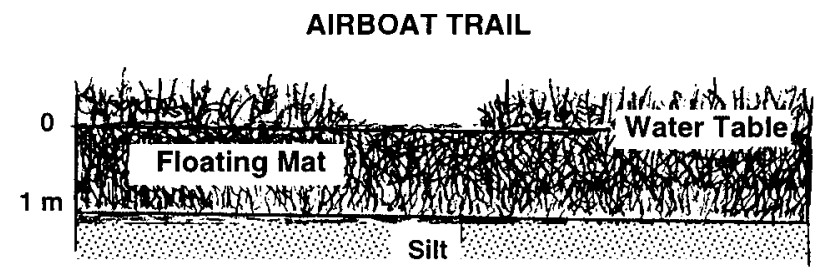

b)

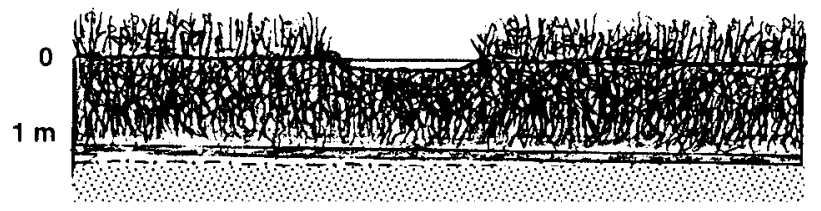

c)

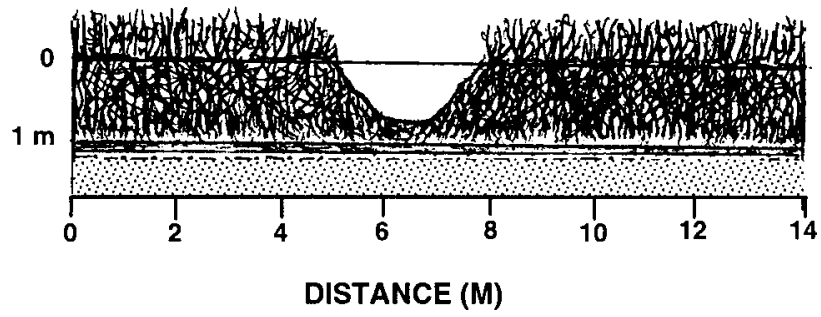

FIG. 5. Cross-sectional diagram of a floating mat fen showing the development of an airboat main trail over time from a) a secondary trail with only flattened vegetation to b) a trail with complete removal of the emergent vegetation, open water, and some mat loss to c) an open-water channel, with flowing water and more than $50 \%$ of the floating mat removed.

interior Alaska are much greater. We also have not evaluated potential indirect impacts on hydrology, effects of noise on wildlife, and conflicts among hunters. Given the magnitude of this disturbance, it is clear that land managers should pay more attention to these impacts and develop approaches to managing this activity. On other federal and state lands, there are regulatory mechanisms for limiting off-road activity to certain areas or to established trails. The capability of the airboats to traverse wetlands with sensitive vegetation and soils makes them different from ordinary watercraft. Thus they should be considered as a separate category of off-road vehicle by the managers of public lands.

\section{ACKNOWLEDGEMENTS}

Funding for this work was provided by the U.S. Army Alaska under the ITAM program, with support from Junior Kerns, William Gosswieler, William Quirk, and Pam Bruce. Robert Lichvar and Ellis Clairain, wetland scientists at USA Waterways Experiment Station (WES), assisted with field studies. Mark Clark, Soil Scientist, Natural Resources Conservation Service, Wasilla, Alaska, described some of the floating mat profiles. Peggy Robinson (U.S. Army Cold Regions Research and Engineering Laboratory) interpreted and digitized the airboat trails. Marilyn Racine and Roger Post (Alaska Department of Fish and Game) helped in the field and reviewed the manuscript. 


\section{REFERENCES}

BOELTER, D.H. 1969. Physical properties of peats as related to degree of decomposition. Soil Science Society of America Proceedings 33:606-609.

EMERS, M., JORGENSON, J.C., and RAYNOLDS, M.K. 1995. Response of arctic tundra plant communities to winter vehicle disturbance. Canadian Journal of Botany 73:905-917.

FORBES, B.C. 1992. Tundra disturbance studies I. Long-term effects of vehicles on species richness and biomass. Environmental Conservation 19:45-48.

HOGG, E.H., and WEIN, R.W. 1988. Seasonal change in gas content and buoyancy of floating Typha mats. Journal of Ecology 76:1055-1068.

JORGENSON, M.T., ROTH, J.E., RAYNOLDS, M.K., SMITH, M.D., LENTZ, W., ZUSI-COBB, A.L. 1996. An ecological land classification for Fort Wainwright, Alaska. Draft report to USA CRREL by ABR Inc. Fairbanks, Alaska.

KRATZ, T.K., and DEWITT, C.B. 1986. Internal factors controlling peatland-lake ecosystem development. Ecology 67:100-107.

KRUSI, B.O., and WEIN, R.W. 1988. Experimental studies on the resiliency of floating Typha mats in a freshwater marsh. Journal of Ecology 76:60-72.

MABIE, D.W., JOHNSON, L.A., THOMPSON, B.D., BARRON, J.C., and TAYLOR, R.B. 1989. Responses of wintering whooping cranes to airboat and hunting activities on the Texas coast. Wildlife Society Bulletin 17:249-253.
PÉWÉ, T.L. 1975. Quaternary geology of Alaska. U.S. Geological Survey Professional Paper 835. Washington, D.C.: U.S. Geological Survey. 145 p.

RACINE, C.H., and AHLSTRAND, G.M. 1991. Thaw response of tussock-shrub tundra to experimental all-terrain vehicle disturbances in south-central Alaska. Arctic 44:31-37.

RACINE, C.H., and WALTERS, J.C. 1994. Groundwater-discharge fens in the Tanana Lowlands, Interior Alaska, USA. Arctic and Alpine Research 26:418-426.

RACINE, C.H., JORGENSON, M.T., and WALTERS, J.C. In press. Thermokarst vegetation in lowland birch forests on the Tanana Flats, Interior Alaska, U.S.A. In: Lewkowicz, A.G., and Allard, M., eds. Proceedings of the 7th International Conference on Permafrost, 23-27 June 1998, Yellowknife, NWT. Université Laval, Collection Nordicana No. 57.

RICKARD, W.E., and BROWN, J. 1974. Effects of vehicles on arctic tundra. Environmental Conservation 1:55-62.

SJORS, H. 1988. Vattenklovern, Menyanthes trifoliata - en minimonografi. Svensk Botanisk Tidskrift 82:51-64.

SLAUGHTER, C.W., RACINE, C.H., WALKER, D.A., JOHNSON, L.A., and ABELE, G. 1990. Use of off-road vehicles and mitigation of effects in Alaska permafrost environments: A review. Environmental Management 14(1):63-72.

VIERECK, L.A., VAN CLEVE, K., ADAMS, P.C., and SCHLENTNER, R.E. 1993. Climate of the Tanana River floodplain near Fairbanks, Alaska. Canadian Journal of Forest Research 23:899-913. 